\title{
MENANAMKAN KARAKTER DEMOKRATIS SISWA MENYUSUN ORGANISASI DI KELAS SMP NEGERI 1 JELIMPO KABUPATEN LANDAK
}

\author{
Dada Suhaida ${ }^{1}, \operatorname{Moad}^{2}$, Lindasari $^{3}$ \\ ${ }^{1,2}$ Program Studi Pendidikan Pancasila dan Kewarganegaraan IKIP PGRI Pontianak \\ ${ }^{3}$ Guru Sekolah Menengah Pertama Negeri 1 Jelimpo Kabupaten Landak \\ 1e-mail: civic.link@yahoo.com
}

\begin{abstract}
Abstrak
Tujuan penelitian ini untuk mengetahui dan memperoleh gambaran mengenai; Menanamkan Karakter Demokratis Siswa di SMP Negeri 1 Jelimpo Kabupaten Landak. Metode penelitian ini adalah kualitatif dengan deskriptif, dengan sumber data penelitian 5 orang siswa dan 1 orang guru PPKn. Alat pengumpul data yang digunakan berupa Teknik observasi dengan alat panduan observasi, Teknik komunikasi langsung dengan alat panduan wawancara, dan tenik studi dokumentasi dan alat dokumentasi. Analisis dilakukan dengan pengumpulan data, reduksi data, penyajian data, verfikasi dan penarikan kesimpulan. Hasil penelitian menunjukkan bawah secara umum peran guru PPKn sudah cukup aktif dalam menanamkan karakter demokratis pada siswa kelas VII dalam kegiatan penyusunan organisasi kelas. Hasil penelitian secara khusus menunjukkan; peran guru dalam menanamkan karakter demokratis kepada siswa yakni; memberikan kebebasan kepada siswa dalam mengemukakan pendapat, memberikan pemahaman kepada siswa mengenai perbedaan, memberikan pemahaman kepada siswa mengenai demokrasi; dan siswa juga diberikan kesempatan kepada siswa untuk berpatisipasi aktif dalam penyusunan organisasi kelas, menjadi penyelenggara demokrasi dalam kegiatan penyusunan organisasi kelas.
\end{abstract}

Kata Kunci: Karakter Demokratis, Organisasi Kelas

\begin{abstract}
The purpose of this research is to find out and obtain an overview of; Instilling a Democratic Character for Students in SMP Negeri 1 Jelimpo, Landak Regency. This research method is qualitative descriptive, with the research data source 5 students and 1 teacher of PPKn. The data collection tools used were observation techniques with observation guidance tools, direct communication techniques with interview guides, and documentation study techniques and documentation tools. The analysis was carried out by collecting data, reducing data, presenting data, verifying and drawing conclusions. The results showed that in general, the role of PPKn teachers was quite active in instilling a democratic character in grade VII students in the activities of class organization arrangement. The results of the study specifically show; the role of the teacher in instilling a democratic character in students, namely; giving freedom to students in expressing opinions, providing understanding to students about differences, providing understanding to students about democracy; and students are also given the opportunity for students to participate actively in the preparation of class organizations, to become organizers of democracy in activities to organize class organizations.
\end{abstract}

Keywords: Democratic Character, Class Organization

\section{PENDAHULUAN}

Pendidikan sebagai suatu upaya mencerdaskan kehidupan bangsa diharapkan mampu memberikan peran dan andilnya dalam meningkatkan pembanguann sumber daya manusia yang menjadi perioritas utama dalam pedidikan, hal ini mendorong pemerintah untuk mengadakan wajib belajar Sembilan tahun. Karena itu pendidikan harus memberikan kontribusi yang nyata terhadap pembangunan tersebut. Sagala (2004: 2) menyatakan, "Pendidikan merupakan proses pembentukkan kemampuan dasar yang fundamental baik menyangkut daya pikir atau daya intelektual maupun daya emosional atau perasaan yang diarahkan kepada tabiat kepada manusia dan kepada sesama".

Pendidikan memiliki peran yang sangat menentukan bagi perkembangan dan perwujudan dari individu, terutama bagi pembangunan bangsa dan Negara. Tujuan pendidikan pada umumnya adalah 
menyediakan lingkungan yang baik agar anak didik dapat mengembangkan bakar kemampuannya secara optimal. Sebagaimana tertuang dalam kebijakan pemerintah yakni menetapkan Undang-undang Nomor 20 Tahun 2003 Tentang Sistem Pendidikan Nasional (2003:6) pasal 3 yang menyatakan :

Pendidikan Nasional berfungsi mengembangkan kemampuan dan membentuk watak serta peradaban bangsa yang bermartabat dalam rangka mencerdaskan kehidupan bangsa, bertujuan untuk berkembangya peserta didik agar jadi manusia yang beriman dan bertakwa kepada Tuhan Yang Maha Esa, berakhlak mulia, berilmu, cakap, kreatif, mandiri, dan menjadi warganegara yang baik demokratis serta bertanggung jawab.

Sebagaimana tujuan Pendidikan Nasional, maka perbaikan sumber daya manusia yang cerdas, terampil, mandiri, dan berakhlak mulia serta bertanggung jawab harus terus diupayakan melalui proses pendidikan. Berdasarkan bunyi pasal di atas dapat dipahami, bahwa tujuan pendidikan nasional bertujuan memperbaiki sumber daya manusia yang cerdas, terampil, mandiri, dan berakhlak mulia serta bertanggung jawab harus terus diupayakan melalui pendidikan, pendidikan harus mampu menjawab tantangan zaman dan mampu membentuk karakter manusia.

Azzet, (2013:11) menyatakan bahwa, karakter adalah sifat yang dimiliki oleh setiap individu, yang tiap-tiap orang memiliki karakteristik masing-masing. Karakter seorang individu terbentuk sejak dari kecil karena pengaruh genetik dan lingkungan sekitar. Proses pembentukkan karakter secara sadar maupun tidak tidak akan dipengaruhi dengan cara individu tersebut mamandang diri dengan lingkungannya dan akan tercermin dalam prilaku sehari-hari. Selanjutnya karakter merupakan nilai-nilai perilaku manusia yang erat hubungannya dengan Tuhan Yang Maha Esa, diri sendiri, sesame manusia, lingkungan dan kebangsaan yang terwujud dalam pikiran, sikap, perasaaan, perkataan, dan perbuatan yang berlandaskan norma-norma agama, hukum, tata krama, budaya dan adat istiadat. Sehingga perseta didik sangat penting untuk mendapatkan pendidikan karakter, karena karakter bertujan untuk memperkuat akhlak dan sifat terpuji bagi peserta didik karena kepandaain di bidang pendidikan saja belum cukup tanpa bekal moral dan karakter kuat (Faturahman, dkk, 2013:10).

Dapat diasumsikan bahwa, karakter adalah sifat individu yang diperoleh sejak dari kecil dan akan dipengaruhi oleh genetik dan lingkungan sekitar di mana individu tersebut tinggal dan berinteraksi. Yaumi (2014:82-83) menyatakan, bahwa aspek yang perlu dan dikembangkan dalam pendidikan karakter disekolah antara lain: 1) Religius; (2) Jujur; (3) Toleransi; (4) Disiplin; (5) Kerja keras; (6) Kreatif; (7) Mandiri; (8) Demokratis; (9) Rasa Ingin Tahu; (10) Semangat Kebangsaan; (11) Cinta Tanah Air; (12) Menghargai Prestasi; (13) Bersahabat dan Komunikatif; (14) Cinta Damai; (15) Gemar Membaca; (16) Peduli Lingkungan; (17) Peduli Sosial; (18) Tanggung Jawab.

Salah satu kondisi yang esensil dalam pembangunan karakter dalam penanaman karakter kepada siswa yakni salah satunya karakter demokratis. Karakter demokratis sangat diperlukan dimiliki dalam kehidupan masyarakat. Karakter demokratis diartikan sebagai cara berpikir dan bertindak yang menilai sama hak dan kewajiban dirinya dan orang lain (Yaumi, 2014:82). Sejalan dengan pendapat di atas Faturahman, dkk, (2013:19) menguraikan beberapa indikator yang dapat digunakan untuk mendeskripsikan karakter demokratis antara lain: 1) Memilih ketua kelompok berdasarkan suara Menanamkan karakter demokratis siswa menyusun organisasi di kelas SMP Negeri 1 Jelimpo 
terbanyak; 2) Memberikan suara dalam pemilihan di kelas dan di sekolah; 3) Mengemukakan pikiran tentang teman-teman sekelas; 4) Ikut membantu melaksanakan program ketua kelas; 5) Membiasakan bermusyawarah; 6) Mengemukakan pendapat tentang teman yang menjadi pemimpinya; 7) Menerima kekalahan dalam pemilihan dengan ikhlas.

Sikap demokratis sangat diperlukan dalam pemerintahan Indonesia yang demokratis. Perkembangan baru menunjukkan bahwa demokrasi tidak hanya dipahami sebagai bentuk pemerintahan dan sistem politik, tetapi demokrasi dipahami sebagai sikap hidup atau pandangan hidup demokratis. Demokrasi membutuhkan usaha nyata dari setiap warga maupun penyelenggara negara untuk berperilaku sedemikian rupa sehingga mendukung pemerintahan atau sistem politik demokratis (Winarno, 2015: 97).

Tanpa adanya karakter demokratis, maka solidaritas akan tidak berjalan baik, penghargaan terhadap perbedaan kian luntur dimana dilanda egoisme semata antar individu maupun kelompok. Secara positif karakter demokratis banyak memberikan manfaat baik secara moril dan materil. Harapanya di sekolah, peserta didik mempunyai karakter demokratis dan bisa mengimplementasikanya dengan baik. Pembentukan dan penanaman karakter demokratis di sekolah memiliki peran penting, yang dilakukan melalui bimbingan, pemahaman, stimulus, dan keyakinan supaya karakter demokratis ada pada peserta didik, dan semakin berkembang dapat di implementasikan dengan penuh kesadaran.

Penanaman karakter demokratis di sekolah dapat dilakukan dengan membangun kultur demokrasi yang berkeadaban kepada siswa dengan menuntut keterlibatan aktif siswa dalam penyusunan organisasi kelas. Organisasi kelas sendiri merupakan organisasi terkecil yang berada di suatu sekolah atau bisa dikatakan miniatur sebuah negara yang dijalankan dalam ruang lingkup yang paling kecil. Sejalan dengan paparan di atas menurut Winataputra (2012:9) berpendapat bahwa: "Pendidikan kewarganegaraan dipersekolahan (school civics) memiliki peranan strategis dalam mewujudkan pengembangan budaya kewarganegaraan demokratis, karena pendidikan kewarganegaraan merupakan salah satu modal dasar dalam mewujudkan kehidupan bermasyarakat yang berbudaya dan beradab. Untuk tujuan itu, maka kurikulum dan proses pembelajaran perlu diupayakan agar lebih mengarah pada tujuan pembangunan karakter bangsa yang diwujudkan dalam bentuk transformasi pengetahuan kewarganegaraan (civic knowledge), perilaku kewarganegaraan (civic disposition), dan kemampuan kewarganegaraan (civic skills) yang dapat mendukung berkembangnya budaya kewarganegaraan (civic culture)".

Sehubungan dengan paparan di atas maka pendidikan merupakan lapangan yang sentral untuk memberikan pendidikan demokrasi kepada generasi muda, baik melalui jalur pendidikan Formal (sekolah dan Perguruan Tinggi), Non formal (Pendidikan diluar sekolah dan informal), Informal (pergaulan dirumah dan masyarakat). Lingkungan sekolah merupakan salah satu tempat yang tepat untuk penanaman karakter demokratis peserta didik yang dilakukan oleh guru. Hal tersebut dikarenakan lingkungan sekolah seorang anak diberikan pendidikan, bimbingan, pemahaman, dan keyakinan, sehingga dapat mengerti pentingnya karakter demokratis dimiliki dan diimplementasikan dalam berbagai kegiatan pembelajaran di 
sekolah, khususnya dalam penyusunan organisasi kelas dimana seorang anak diajarkan untuk bersikap demokratis dengan mengedepankan nilai-nilai demokrasi dalam proses penyusunan organisasi kelas.

Penelitian yang dilakukan Asiati Afrik Rizana, Abdul Hamid Wahid dan Chusnuk Muali (2017:2) dengan judul "Smart Parenting Demokratis dalam Membangun Karakter Anak". Hasil penelitian menujukkan bahwa dalam membangun karakter anak sangat dipengaruhi oleh pola asuh dalam keluarga, peran orang tua menjadi orang pertama dalam hal menanamkan karakter anak. Pola asuh demokratis dianggap sangat cocok serta efektif dalam mengembangkan karakter anak. Dapat diartikan bahwa, dalam menanamkan karakter anakpun diperlukan pola asuh yang demokrasi sehingga anak lebih mudah memahami dan melakukan. Penelitian selanjutnya dilakukan oleh Moh. Wahyu Kurniawan dan Adi Slamet Kusumawardana (2020:7) dengan judul strategi penguatan pendidikan karakter dalam menumbuhkan sikap demokrasi siswa. Tujuan penelitian Pertama menganalisis strategi penanaman nilainilai karakter dalam membentuk sikap demokratis siswa. Kedua, Menganalisis strategi penanaman nilainilai karakter dalam membentuk sikap demokratis siswa. Hasil penelitian mengambarkan bahwa, penguatan pendidikan karakyer di lingkungan sekolah diintegrasikan dalam beberapa pendekatan, salah satunya ialah kegiatan proses belajar mengajar pada setiap pembelajaran. Kedua, penguatan pendidikan karakter dalam membentuk sikap demokratis siswa dan pada kegiatan pembelajaran juga didukung dengan kegiatan intra dan ekstra kurikuler, temuan lain adalah pada keterlibatan siswa dan orang tua diajak dalam pengambilan keputusan sekolah.

Dapat diasumsikan, bahwa penanaman karakter demokratis dapat diintegrasikan dalam pembelajaran dengan melibatkan siswa dan orang tua dalam pengambilan keputusan sekolah, sehingga orang tua juga berperan dalam penanaman karakter demokratis kepada anak yang akan berdampak pada karakter anak pada pembelajaran di sekolah. Adapun yang menjadi alasan peneliti tertarik meneliti bperan guru dalam menanamkan karakter demokratis siswa yaitu; pertama, ketertarikan peneliti sendiri dengan materi demokrasi; kedua, generasi muda merupakan bagian tak terpisahkan dalam proses demokrasi yang harus dipersiapkan menjadi calon-calon pemilih pemula yang mau dan mampu hidup demokratis; Ketiga, peneliti ingin mengetahui sejauh mana pemahaman dan implementasi nilai demokrasi siswa kelas VII di SMP Negeri 1 Jelimpo Kabupaten Landak saat ini sehingga akan memberikan manfaat bagi berbagai pihak dalam upaya penanaman nilai karakter demokratis di sekolah maupun di masyarakat. Sejalan dengan paparan di atas adapun yang menjadi alasan peneliti memilih SMP Negeri 1 Jelimpo Kabupaten Landak dikarenakan berdasarkan observasi peneliti terlihat bahwa, karakter demokrasi siswa sudah dimiliki dengan melaksanakan kegiatan penyusunan organisasi kelas dan pemilihan ketua osis melalui proses demokrasi, dimana peserta didik secara aktif menggunakan hak pilihnya dalam pelaksanaan demokrasi, namun pelaksanaanya belum optimal, hal tersebut dikarenakan terdapat sebagian besar siswa/i yang cenderung ikut-ikutan dalam melakukan aktivitas tersebut, hal tersebut merupakan gambaran belum optimalnya peran guru dalam menanamkan karakter demokratis dalam pembelajaran PPKn. 
Sementara itu hal lain yang dapat menggambarkan permasalahan mengenai sikap demokratis siswa di SMPN 1 Jelimpo Kabupaten Landak yaitu; 1) Tidak digunakannya ruang kebebasan berbicara; 2) sebagian besar siswa malu menyampaikan pendapatnya; 3) Terdapat siswa yang tidak mau mendengar pendapat orang lain; 4) Siswa kurang berpartisipasi dalam membantu melaksanakan program ketua kelas; 5) Terdapat siswa yang tidak menerima kekalahan dalam pemilihan ketua kelas, merupakan gambaran masih rendahnya sikap demokratis yang dimiliki siswa. Permasalahan di atas muncul dikarenakan siswa belum sepenuhnya mengetahui nilai-nilai demokratis yang seharusnya mereka miliki dan mereka kembangkan dalam proses pembelajaran maupun dalam pergaulan mereka dimasyarakat, hal tersebut tentu saja menjadi titik tolok guru PPKn dalam berperan menanamkan karakter demokratis siswa.

Sejalan dengan paparan di atas peran guru dalam penanaman karakter demokratis siswa Kelas VII SMP Negeri 1 Jelimpo Kabupaten Landak seharusnya dapat dilaksanakan dan dikembangkan secara optimal dalam berbagai kegiatan pembelajaran maupun kegiatan organisasi untuk berpartisipasi dalam penyusunan organisasi kelas SMP Negeri 1 Jelimpo Kabupaten Landak.

\section{METODE PENELITIAN}

Metode dapat diartikan sebagai suatu cara maupun Teknik yag digunakan dalam sebuah penelitian. Metode penelitian ini menggunakan metode kualitatif. Penelitian kualitatif adalah sebagai prosedur penelitian yang menghasilkan data deskriptif berupa kata-kata atau lisan dari orang-orang dan perilaku yang bisa diamati (Moleong, 2012 :4).

Berdasarkan pendapat tersebut dapat diasumsikan bahwa metode kualitatif adalah metode penelitian yang berupaya untuk menggunakan fenomena yang terjadi sesuai dengan alami. Sebagaimana yang dikemukakan Bogdan dan Biklen (Sugiyono, 2014:22) menyatakan ada beberapa ciri-ciri penelitian kualitatif yakni:
a. Dilakukan pada kondisi yang alamiah
b. Bersifat deskriptif
c. Lebih mementingkan proses daripada hasil
d. Induktif
e. Makna merupakan hal yang esensial

Metode penelitian kualitatif dipilih dalam penelitian ini dengan tujuan untuk memperoleh informasi dan gambaran secara jelas tentang "peran guru PPKn dalam menanamlan karakter demokratis siswa kelas VII dalam Menyusun organisasi kelas di SMP Negeri 1 Jelimpo Kabupaten Landak”. Bentuk penelitian ini adalah deskriptif. Penelitian deskriptif adalah salah satu jenis penelitian yang tujuanya menyajikan gambaran lengkap mengenai setting sosial atau hubungan antara fenomena yang di uji. Menurut Sugiyono, (2014:22) mengatakan bahwa penelitian kualitatif bersifat deskriptif dengan data yang terkumpul berupa kata-kata atau gambar. Sejalan dengan pendapat di atas Satori, dan Komariah, (2012:25) mengatakan bahwa bentuk penelitian deskriptif adalah suatu pendekatan penelitian yang mengungkap situasi sosial tertentu dengan mendeskripsikan kenyataan dengan benar, dibentuk oleh kata- 
kata berdasarkan teknik pengumpulan dan analisis data yang relevan yang diperoleh dari situasi yang alamiah.

Berdasarkan pendapat di atas maka dapat dimaknai bahwa bentuk penelitian deskriptif merupakan bentuk penelitian yang berusaha mendeskripsikan suatu gejala, atau fenomena dari peristiwa yang terjadi. Bentuk penelitian deskriptif dipilih karena penulis ingin melakukan analisis mendalam bagaimana "Peran Guru PPKn Dalam Menanamkan Karakter Demokratis Siswa Kelas VII dalam Menyusun Organisasi Kelas di SMP Negeri 1 Jelimpo Kabupaten Landak”. Adapun tempat penelitian ini bertempat di Sekolah Menengah Pertama Negeri 1 Jelimpo Kabupaten Landak.

Data dan sumber data dalam penelitian ini adalah, strategi penanaman karakter demokratis dan peran guru PPKn dalam menanamkan karakter demokratis siswa kleas VII dalam Menyusun organisasi kelas. Sedangkan sumber data dalam penelitian ini 1 orang guru PPKn dan 5 orang siswa kelas VII. Alasan pemilihan sumber data 1 orang guru PPKn dikarenakan guru PPKn tersebut mengajar di kelas VII. Untuk pemilihan sumber data siswa kelas VII adalah 3 orang merupakan siswa yang aktif dalam proses pembelajaran, dan 2 orang siswa kurang aktif dalam proses pembelajaran. Dan ke 5 siswa tersebut merupakan perwakilan dari seluruh kelas VII.

Sedangkan untuk Teknik dan alat pengumpul data yang digunakan yakni ; 1) tekni observasu langsung adalah cara untuk mengumpulkan data yang dilakukan melalui pengamatan dan pencatatan gejala-gejala yang tampak pada objek penelitian yang pelaksanaanya langsung pada tempat dimana suatu peristiwa, keadaan atau situasi sedang terjadi menggunakan pedoman dan pencatatan data berupa pedoman observasi, pengumpulan data dengan cara terjun kelapangan mengamati dan melihat secara langsung kegiatan pembelajaran menanamkan karakter demokratis dala penyusunan organisasi kelas, 2) Komunikasi langsung adalah dengan kontak langsung secara langsung atau tatap muka dengan sumber data. Zuldafrial (2004:31) adalah "Suatu metode pengumpulan data di mana peneliti untuk mendapatkan data atau informasi yang diperlukan melalui wawancara dengan subjek penelitian”. Teknik ini adalah cara mengumpulkan data yang mengharuskan seseorang peneliti mengadakan kontak langsung secara lisan atau tatap muka dengan sumber data, baik dalam situasi yang sebenarnya maupun dalam situasi yang sengaja dibuat untuk keperluan tersebut. Teknik komunikasi langsung yang penulis maksud adalah penulis mengadakan wawancara langsung terhadap informan yang dijadikan sumber data dalam penelitian ini yaitu; Siswa/i Kelas VII, dan Guru PPKn SMPN 1 Jelimpo Kabupaten Landak, 3) Analisis dokumen dilakukan untuk mengumpulkan data yang bersumber dari arsip dan dokumen baik yang berada di SMPN 1 Jelimpo Kabupaten Landak atau pun yang berada diluar yang ada hubunganya dengan penelitian tersebut.

\section{HASIL PENELITIAN DAN PEMBAHASAN}

Peran guru PPKn dalam Menanamkan Karakter Demokratis Kepada Siswa Kelas VII SMP Negeri 1 Jelimpo Kabupaten Landak. 
Temuan di lapangan menunjukkan bahwa peran guru PPKn dalam menanamkan karakter demokratis siswa dalam Menyusun organisasi kelas di SMP Negeri 1 Jelimpo Kabupaten Landak sudah cukup baik. Peran guru PPKn selama ini dilakukan dengan memberikan kebebasan kepada siswa mengemukakan ide dan pendapatnya, dan menghargai perbedaan pendapat, Selain itu guru juga berperan memberikan pemahaman kepada siswa tentang sikap demokratis dengan tujuan terciptanya sikap yang demokratis, serta Menjadi penyelenggara demokrasi, dengan menyiapkan segala perangkat pembelajaran yang merupakan bentuk praktik langsung dalam demokrasi. Temuan tersebut mengambarkan bahwa guru PPKn sudah berperan aktif dalam menanamkan karakter demokratis kepada siswa dalam proses pembelajaran.

Menurut Hekzew dan Lendon, (Uno, 2009:15) mengemukakan bahwa; Techer is professional person who conducts classes," (Guru adalah seseorang yang mempunyai kemampuan menata dan mengelola kelas. Sementara Uno, (2009:15) menilai guru adalah suatu profesi atau jabatan yang memerlukan keahlian khusus yang tidak dapat dilakukan sembarang orang diluar bidang pendidikan.

Beradasarkan paparan di atas maka dapat dimaknai bahwa guru merupakan suatu profesi, yang berarti suatu jabatan yang memerlukan keahlian khusus yang dilakukan oleh orang dewasa yang memiliki kemampuan dan pengalaman untuk mendidik dan megelola pembelajaran yang tidak dapat dilakukan oleh sembarang orang.

Sebagai pendidik yang profesional, Danin, dan Khairil, (2015: 5) menjelaskan bahwa guru memiliki tugas utama yakni; mendidik, mengajar, membimbing, mengarahkan, melatih, menilai dan mengevaluasi peserta didik. Untuk mencapai tujuan pembelajaran yang telah ditentukan maka seorang guru dituntut memahami peran dan tugas utamanya sebagai pendidik profesional.

Temuan penelitian selanjutnya yakni; (1) Memberikan Kebebasan Kepada Siswa Mengemukakan Pendapat; Mengemukakan pendapat, adalah sarana menyampaikan ide dan gagasan atau pikiran. Kebebasan mengeluarkan pendapat merupakan bagian hak asasi yang dimiliki oleh setiap manusia dan UU menjamin itu. Negara Indonesia sebagai negara hukum secara tegas membarikan jaminan konstitusional terhadap kemerdekaan mengemukakan pendapat warga negaranya.

Kebebasan memberikan pendapat kepada siswa dalam mengemukakan pendapat dapat dilihat pada gambar 1.1 sebagai berikut :

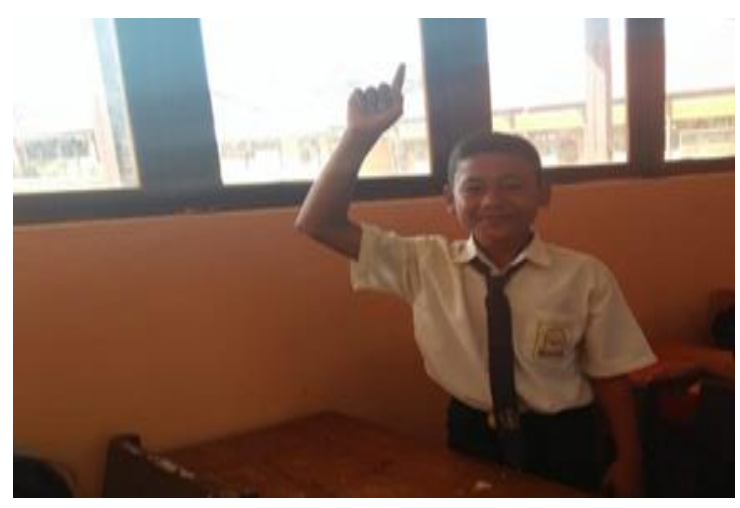


Gambar 1.1 Siswa mengacungkan tangan kepada guru PPKn untuk memberikan pendapat pada pemilihan organisasi kelas

Gambar di atas menunjukkan salah satu siswa kelas VII SMP Negeri 1 Jelimpo Landak sedang mengacungkan tangan kepada guru PPKn. Pada saat itu guru PPKn meminta siswa untuk memberikan pendapatnya pada proses pemilihan organisasi kelas. Berdasarkan hasil observasi dan wawancara guru PPKn berperan dengan sungguh-sungguh dalam memberikan kebebasan kepada siswa dalam mengemukakan pendapat di depan kelas pada pemilihan organisasi kelas.

Selanjutnya gambaran peran guru dalam menanamkan karakter demokratis di kelas VII SMP Negeri 1 Jelimpo Landak dalam proses pemilihan organisasi kelas dapat dilihat pada gambar 1.2 sebagai berikut:

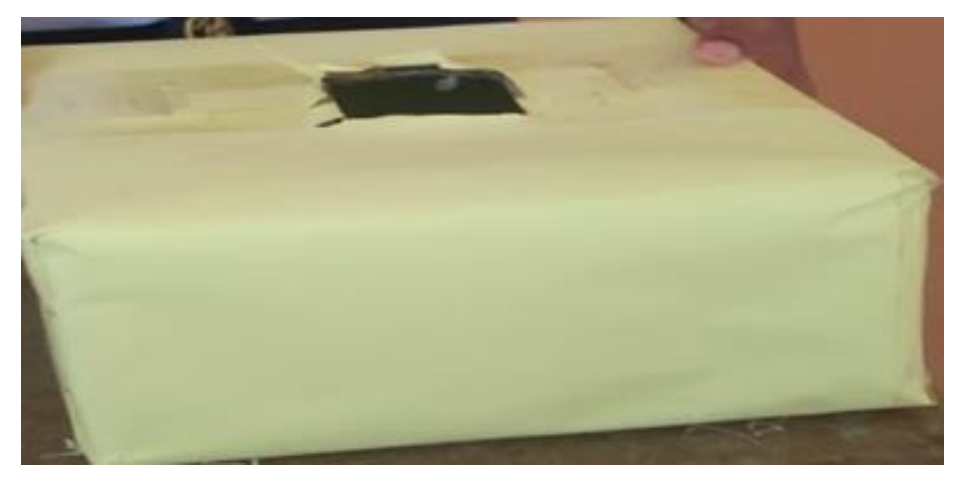

Gambar 1.2 Kotak Pemilihan Suara

Gambar 1.2 menunjukkan bahwa kotak suara sudah disiapkan guru bersama siswa sebagai fasilitas dalam menyimpan kertas pemilihan suara. Artinya pemilihan organisasi kelas tergambar secara jujur, langsung dan rahasia.

Selanjutnya temuan penelitain terlihat pada gambar 1.3 sebagai berikut:

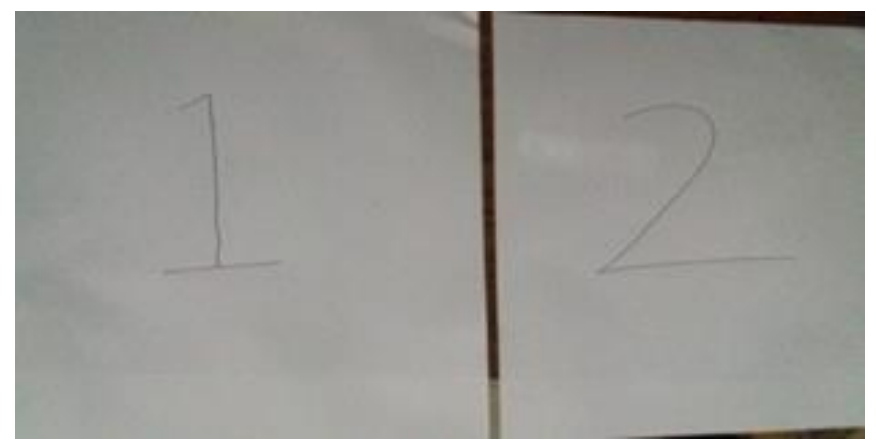

Gambar 1.3 Karton Calon Ketua Kelas dan Wakil Ketua Kelas

Gambar 1.4 menggambarkan sebuah dua buah kertas yang bertulskan nomor 1 dan 2 . kertas tersebut dibuat guru, untuk menentukan nomor urut bagi para peserta didik yang akan mencalonkan diri sebagai ketua dan wakil ketua kelas.

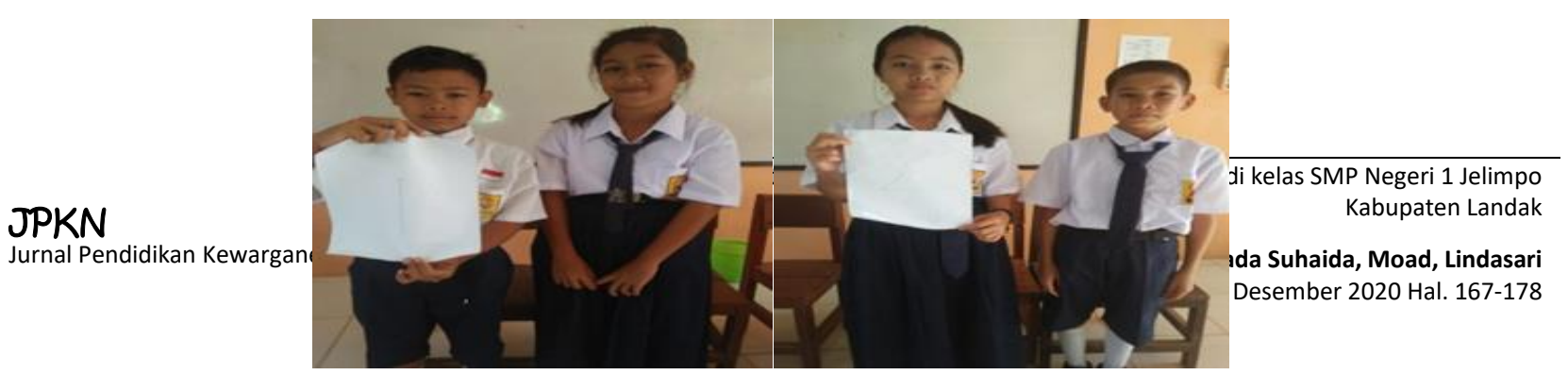


Gambar 1.4 Calon ketua kelas dan wakil ketua kelas

Gambar 1.4 menggambarkan dua pasangan calon ketua dan wakil ketua kelas menunjukkan nomor urut peserta yang nantinya akan dipilih dalam proses demokrasi kelas. Gambar tersebut merupakan bukti bahwa guru PPKn sudah berhasil berperan dalam menanamkan karakter demokratis dalam proses pemilihan organisasi kelas.

Gambar selanjutnya 1.5 susana pemilihan dan siswa memberikan hak suaranya, sebagai berikut :

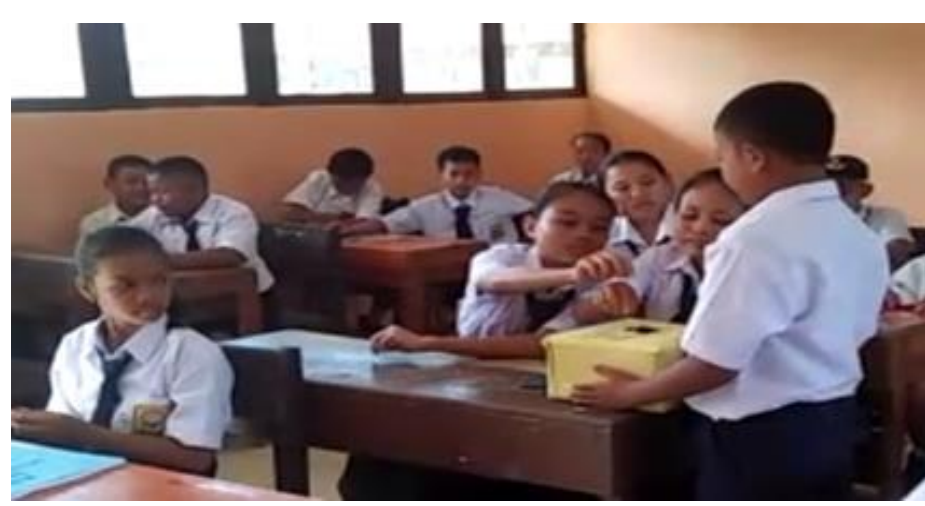

Gambar 1.5 susana pemilihan dan siswa memberikan hak suaranya

Gambar 1.5 menggambarkan bahwa guru sudah berperan melaksanakan penanaman karakter demokratis kepada siswa dalam pemilihan organisasi kelas. Hal tersebut terlihat dalam penyusunan organisasi kelas siswa sudah aktif berpartisipasi dalam penyusunan organisasi kelas, baik menyalurkan pilihanya maupun membantu guru mengambil hak suara peserta didik dalam pemilihan ketua dan wakil ketua kelas.

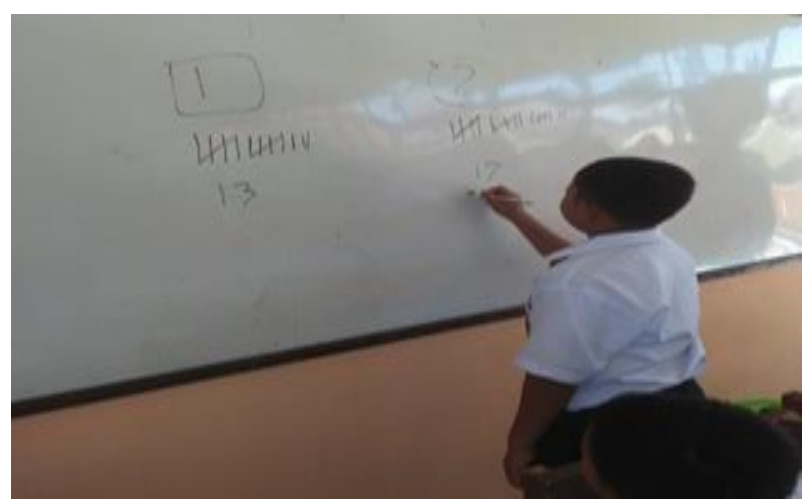




\section{Gambar 1.6 Perhitungan Suara}

Gambar 1.6 menggambarkan bahwa setiap proses penyusunan organisasi kelas guru PPKn senantiasa menjadi fasilitator yang senantiasa memberikan motvasi kepada peserta didik sehingga terciptanya karakter demokratis. Dari temuan hasil penelitian pada dokumentasi di atas, dapat tergambar bahwa guru PPKn sudah berperan bersama-sama siswa dalam menanamkan karakter demokratis dalam proses pemilihan organisas kelas, dan peran guru PPKn dapat dikatakan cukup baik dengan melibatkan siswa dalam proses persiapan, pemilihan dan perhitungan suara.

Berdasarkan temuan penelitian tersebut dapat diasumsikan bahwa guru PPKn sudah berperan dalam memberikan kebebasan siwa menyampaikan pendapat kepada siswa sebagai hak dan kewajiban warga negara. Hal tersebut tertuang dalam Undang-Undang Dasar 1945 tepatnya pada pasal 28 menegaskan bahwa; "Kemerdekaan berserikat dan berkumpul, mengeluarkan pikiran dengan lisan dan tulisan, dan sebagainya ditetapkan dengan undang-undang”. Kemudian dipertegas dalam pasal 28E ayat (3) yang menyatakan bahwa setiap orang berhak atas kebebasan berserikat, berkumpul, dan mengeluarkan pendapat.

Selama ini dalam proses pembelajaran di kelas, guru PPKn senantiasa memberikan kesempatan kepada siswa menyampaikan ide dan gagasanya. sering kali terlihat siswa belum terlalu berani mengamukakan pendapatnya, namun Guru PPKn senantiasa memotivasi dan memunculkan stimulus sehingga siswa pun termotivasi. Kebebasan mengemukakan pendapat seyogyanya merupakan bentuk implemetasi karakter demokratis. Pakar Politik Miriam Budiardjo, (2005:65) menjelaskan ciri-ciri negara yang demokratis yakni;

a) Adanya perlindungan konstitusional, artinya harus menentukan prosedural memperoleh hak-hak yang dijamin.

b) Adanya badan kehakiman yang bebas dan tidak memihak.

c) Adanya pemilihan umum yang bebas.

d) Adanya kebebasan untuk menyatakan pendapat.

e) Adanya kebebasan berserikat, berorganisasi, dan beroposisi.

f) Adanya pendidikan kewarganegaraan

Memberikan Pemahaman Kepada Siswa Untuk Menghargai Perbedaan; Perbedaan adalah suatu hal yang tidak bisa dipungkiri oleh setiap orang. Setiap manusia seyogyanya memiliki perbedaan, baik secara fisik, kepribadian, pola pikir, serta ide dan gagasan. Perbedaan pendapat ini sering sekali memunculkan permasalahan, dan merusak tatanan sendi kehidupan yang lain, yang nantinya dapat merusak semangat demokrasi itu sendiri apabila tidak disikapi dengan arif. Kenyataan ini, menurut Sumantri (Winaputra 2012:103) disebut "undemocratic democracy," yakni suatu tatanan kehidupan berbangsa dan bernegara yang struktur (institusi) demokrasinya sudah ada, tetapi semangat dan perwujudannya masih jauh dari cita-cita demokrasi. 
Hal tersebut terjadi lanataran masyarakat masih belum mempunyai pengetahuan dan pemahaman yang benar tentang sistem demokrasi itu sendiri. Cholisin, (2013:111) menjelaskan, pada dasarnya warga negara yang demokratis memiliki kultur dan nilai budaya demokrasi. Untuk itu guru berperan dalam memberikan pemahaman, sehingga dapat mengambangkan kultur demokrasi yang baik kepada siswa.

Seorang guru yang demokratis senantiasa diharapkan memiliki pemahaman yang baik dalam meciptakan sebuah proses pembelajaran yang memungkinkan peserta didik secara aktif menyampaikan ide dan gagasanya. Memberikan Pemahaman Tentang Karakter Demokratis; Selama ini, dalam proses pembelajaran di kelas, peran guru sudah terlihat dengan memberikan pemahaman terhadap materi yang akan diberikan,misalnya saja ketika memulai proses pemilihan ketua kelas. guru terlebih dahulu menjelaskan pengertian demokrasi, dan bagaimana kewajiban warga negara dalam proses demokrasi. Memberikan motivasi; Selama ini dalam proses belajar mengajar guru senantiasa membangun kepercayaan dengan memberikan motivasi terhadap siswa dengan ajakan, maupun penghargaan berupa pujian setiap siswa melakukan dengan baik kegiatan pemilihan organisasi kelas.

\section{SIMPULAN}

Berdasarkan hasil penelitian dan pembahasan dapat disimpulkan bahwa, peran guru PPKn sudah dilakukan dengan baik dan optimal, hal tersebut dibuktikan dengan guru sudah berperan memberikan kebebasan kepada siswa dalam mengemukakan pendapat baik lisan maupun tulisan dalam proses pemilihan organisasi kelas, guru juga menyampaikan pemahaman dalam proses dan teknis pemilihan organisasi kelas, guru ikut memberikan motivasi kepada siswa yang malu dalam mengemukakan pendapat dalam proses pemilihan ketua kelas dan wakil ketua kelas, dan guru turut serta melibatkan siswa dalam proses pemilihan ketua kelas dan wakil ketua kelas yakni, guru Bersama siwa menyiapkan kotak suara, menyiapkan karton pemilihan calon ketua kelas dan wakil ketua kelas.

\section{DAFTAR PUSTAKA}

Asiatik Afrik Rozana, Abdul Hamid Wahid dan Chusnul Muali. (2017) Smart Parenting Demokrasi Dalam Membangun Karakter Anak. http://ejournal.uin-suka.ac.id/tarbiyah/alathfal. [diacces 15 Oktober 2020]

Azzet, A.M. (2013). Urgensi Pendidikan Karakter di Indonesia: Revitalisasi Pendidikan Karakter Terhadap Keberhasilan Belajar dan Kemajuan Bangsa. Yogjakarta: AR-Ruz Media.

Budiardjo, M. (2005). Dasar-dasar Ilmu Politik. Jakarta: Gramedia Pustaka Utama

Cholisin. (2013) Ilmu Kewarganegaraan (Civics). Yogjakarta: Ombak

Danim \& Kahiril (2013). Profesi Kependidikan. Bandung; Alfabeta

Faturahman, dkk. (2013) Pengembangan Pendidikan Karakter. Bandung: PT Refika Aditama

Moh. Wahyu Kurniawan dan Adi Slamet Kusumawardana, (2020). Strategi Penguatan Pendidikan Karakter dalam Menumbuhkan Sikap Demokratis Siswa. http://ejournal.unsri.ac.id/jbt/article. [diacces 15 Oktober 2020]

Moleong, (2012). Metodelogi Penelitian Kualitatif. Bandung; PT Remaja Rosdakarya Offset

Satori \& Komariah. (2012). Metodelogi Penelitian Kualitatif. Bandung; Alfabeta 
Sugiyono, (2014). Metode Penelitian Pendidikan, pendekatan kuantitatif, kualitatif dan R\&D. Bandung: Alfabeta.

Undang-undang Republik Indonesia Nomor 20 Tahun 2003. Tentang Sistem Pendidikan

Uno, Hamzah B. (2009). Teori motivasi dan Pengukurannya (Analisis di Bidang Pendidikan). Jakarta : Bumi Aksara.

Winarno. (2015). Paradigma Baru Pendidikan Kewarganegaraan. Jakarta: Sinar Grafika

Winataputra, S. U. (2012). Pendidikan Kewarganegaraan dalam perspektif Pendidikan Untuk Mencerdaskan Kehidupan Bangsa (Gagasan, Instrumentasi, dan Praksis). Bandung: Widya Aksara Press

Yaumi. (2014). Pendidikan Karakter Landasan, Pilar dan Implementasi. Jakarta; Prenadamedia Group.

Zuldafrial. (2004). Penelitian Kualitatif. Surakarta: Yuma Pustaka 